\title{
Implications of uncertainty and scale in carbon emission estimates on locally appropriate designs to reduce emissions from deforestation and degradation (REDD+)
}

\author{
Betha Lusiana $\cdot$ Meine van Noordwijk • Feri Johana • \\ Gamma Galudra $\cdot$ S. Suyanto $\cdot$ Georg Cadisch
}

Received: 9 February 2013 / Accepted: 8 August 2013 / Published online: 28 September 2013

(C) The Author(s) 2013. This article is published with open access at Springerlink.com

\begin{abstract}
This study combined uncertainty analysis of carbon emissions with local stakeholders' perspectives to develop an effective Reducing Emission from Deforestation and Degradation (REDD+) scheme at the district level. Uncertainty of carbon emission estimates depends on scale while local stakeholders' views on plausible REDD+ schemes influence and limit transaction costs. The uncertainty analysis formed the basis for determining an appropriate scale for monitoring carbon emission estimates as performance measures for REDD+ incentives. Our analysis of stakeholder' perspectives explored (i) potential location and activities for lower emission development pathways, and (ii) perceived fair allocation of REDD+incentives. Our case study focused on frontier forest in Tanjung Jabung Barat District, Jambi, Indonesia. The uncertainty analysis used Monte Carlo simulation techniques using known inaccuracy of land cover classification and variation in carbon stocks assessment per land cover type. With decreasing spatial resolution of carbon emission maps, uncertainty in carbon estimates decreased. At $1 \mathrm{~km}^{2}$ resolution uncertainty dropped below $5 \%$, retaining most of the coarser spatial variation in the district. Fairness, efficiency and transaction cost issues in the design of REDD+ mechanisms were readily recognized by local stakeholders, who converged on an equal allocation to short-term efficiency (emission reduction activities) and long-term fairness (alternative livelihood development). A striking difference occurred in desirable transaction costs (which include monitoring, reporting and verification), with Non-Governmental Organizations (NGOs) aiming for $8 \%$, while government and researchers accepted transaction costs of $40 \%$. Feasible measures for emission reduction in the district, derived from a participatory planning process, are compatible with the $1 \mathrm{~km}^{2}$ spatial resolution of performance measures.
\end{abstract}

Electronic supplementary material The online version of this article (doi:10.1007/s11027-013-9501-z) contains supplementary material, which is available to authorized users.

B. Lusiana · G. Cadisch

Institute of Plant Production and Agroecology in the Tropics and Subtropics, University of Hohenheim, Garbenstr. 13, 70599 Stuttgart, Germany

B. Lusiana $(\bowtie) \cdot$ M. van Noordwijk $\cdot$ F. Johana $\cdot$ G. Galudra $\cdot$ S. Suyanto The World Agroforestry Centre (ICRAF) - Southeast Asian Regional Office, Jl. CIFOR, PO. BOX 161, 16001 Bogor, Indonesia

e-mail: b.lusiana@cgiar.org 
Keywords Effective REDD+ design - Fairness and efficiency - Low-emission development . Scale dependence $\cdot$ Uncertainty of carbon emission

\section{Introduction}

Land use change, in particular tropical deforestation, is a major source of carbon (C) emissions. From the 1960's until now, the amount of land use based C emissions has been relatively stable at about $1.1 \mathrm{Pg} \mathrm{C} /$ year. However, its contribution to global $\mathrm{C}$ emissions and the location of hotspots has changed. In the 1960's, land use based emissions represented about $30 \%$ of the total anthropogenic emissions, while in the 1990's this was $18 \%$ and in 2010 only $9 \%$ of the total. This is due to the large increase in fossil fuel emissions (Canadell et al. 2007, Peters et al. 2012). Globally terrestrial ecosystems are still a net sink for C, sequestering $26 \%$ of C emitted (Le Quere et al. 2009). Thus, maintaining forest and other tree-based systems remains highly desirable.

A scheme called Reducing Emissions from Deforestation and Forest Degradation (REDD) has been proposed by the international community to assist developing nations to reduce their Green House Gases (GHG) emissions that arise from forest conversion and degradation. Under this scheme, countries will receive incentives or compensation for slowing down or avoiding forest conversion and degradation (Agrawal et al. 2011). An extension of the REDD scheme, called Reducing Emission from Deforestation and Degradation (REDD+), includes activities that promote forest management and $\mathrm{C}$ sequestration.

Finding an effective design to implement REDD+ that strikes a good balance between fair and efficient objectives has been a challenge to date (Hoang et al. 2013; Minang and van Noordwijk 2013). Angelsen et al. (2008) and Pedroni et al. (2009) asserted the importance of designing a nested, multi-scale REDD + scheme that includes developing programs at national, sub-national and project level. A well designed nested approach allows the REDD+ scheme to be sensitively designed according to the local forest and tree cover conditions. It would also allow the scheme to match the capabilities and the demands of its local stakeholders thus meeting the REDD safeguard criteria of full and effective participation of relevant stakeholders (Murphy 2011). However, it is important to realize that the ability of a REDD+ policy to meet its national target requires understanding how its processes are linked across scales. An approach to reduce deforestation that is effective at the project level may not be as effective at an aggregated level such as at the district level. Therefore, the issue of scale must be addressed when designing REDD+ activities, such as designing a monitoring and crediting framework, implementation, ownership of credits as well as approval and verification of credits (Cattaneo 2011). Cattaneo (2011) further differentiates the issue of scale as a resolution problem (dependency on pixel resolution) as well as an aggregation problem (dependency on how pixels are aggregated).

Angelsen, et al. (2008) proposed the '3E' criteria in designing a REDD+ scheme: C effectiveness, cost efficiency, and equity. Carbon effectiveness refers to the magnitude of the additional emission reductions achieved and inclusion of significant emission sources. Cost efficiency indicates whether the given emission reduction is achieved at minimum cost; including costs for starting up and running the emission reduction scheme as well as compensation for opportunity costs of foregoing legally allowed activities that would lead to higher emissions. Equity entails, but is not limited to, ensuring that all countries have equal footing in terms of implementation (international level equity) and in terms of sharing the benefits of a REDD+ scheme (national level equity). Similar and complementary criteria have been developed in the realm of payment for environmental services (PES) design: fairness and efficiency 
(van Noordwijk et al. 2012). Efficiency refers to both C effectiveness and cost efficiency, while fairness includes stakeholder perceptions of fairness as well as quantifiable equity.

The main objective of this study was to design effective $\mathrm{C}$ emission reduction activities at sub-national (district) level that can be carried out by stakeholders in the district, with the district government spearheading and coordinating the activities. This study draws upon three parallel activities carried out in Tanjung Jabung Barat (Tanjabar), a high-emission district in Jambi province, which involved: (i) developing district planners' design for $\mathrm{C}$ emission reduction activities that also allow economic growth in the area, (ii) assessing the level of spatial scale/resolution for measuring $\mathrm{C}$ emissions that meet a given error tolerance level, and (iii) compiling local stakeholders' views on fair distribution of potential benefits from REDD+ schemes. Hence, this paper discusses two of the ' $3 \mathrm{E}$ ' criteria: $\mathrm{C}$ effectiveness and equity. The analysis on the cost efficiency for the proposed emission reduction scheme for Tanjabar is discussed in Mulia et al. (2013, this issue), a companion to this paper that calculated the opportunity cost of several emission reduction pathways.

\section{Material and methods}

\subsection{The study site: Tanjung Jabung Barat (Tanjabar) district}

The district of Tanjabar is situated in the north eastern part of Jambi Province, Indonesia with a total area of $5,010 \mathrm{~km}^{2}$ (Fig. 1). Tanjabar is a coastal area with the geographic location of $7.35 \mathrm{~S}-102.64$ $\mathrm{E}$ and $1.45 \mathrm{~S}-103.58 \mathrm{E}$. The site represents a typical forest frontier situation in the topics, where forest conversion is ongoing and carried out by large-scale operators as well as smallholder farmers.

For the past 20 years, widespread conversion of land occurred in the area mainly converting forest to plantations of oil palm (Eleais guineensis Jacq.), rubber (Hevea brasiliensis Muell.

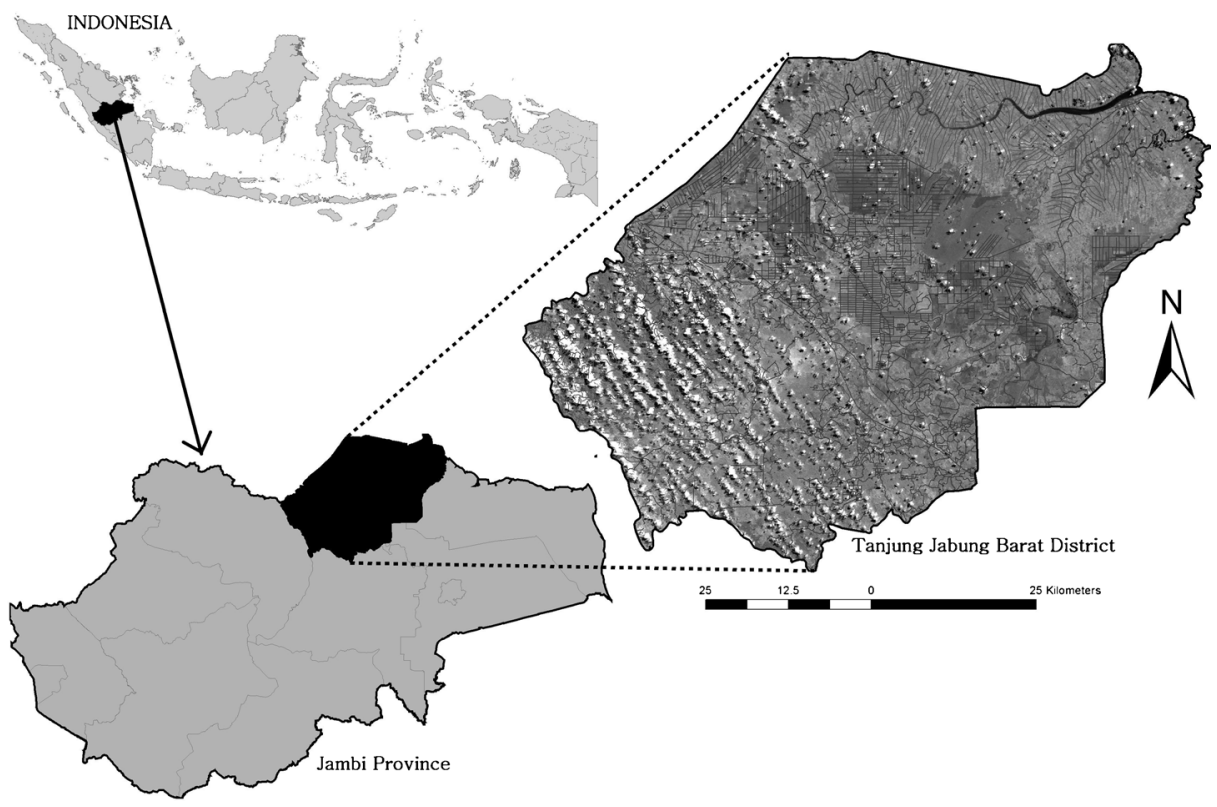

Fig. 1 Location of Tanjung Jabung Barat District, Jambi, Indonesia 
Arg) and acacia (Acacia mangium Willd.). Ekadinata, et al. (2011) showed that conversion from forest to oil palm and acacia plantations alone contributed to $33 \%$ of total emissions in the area during 2000-2009. This calculation was based on estimated losses of aboveground biomass and did not take into account the potentially large $\mathrm{C}$ emissions from drained peat areas (Wösten et al. 1997), which constitutes $40 \%$ of the land. Mulia et al. (2013, this issue) provide a further detailed description of the study area.

\subsection{Planning for a low-emission development pathway in Tanjabar}

The development of a plan for low, carbon, emission trajectories in Tanjabar was carried out by the Tanjabar District Planning and Development Agency (Badan Perencanaan Pembangunan Daerah/Bappeda) in collaboration with the World Agroforestry Centre, Indonesia. Preparing the development plan encompassed several stakeholders meetings, in depth discussions and joint analysis in order to carry out the following activities: (i) development of a land use allocation zone map based on existing land use related maps, i.e. the district spatial land use plan (rencana tata ruang wilayah - RTRW), mining areas, oil palm plantations and timber plantation concessions; (ii) creating detailed development and management plans for each land use allocation zone based on discussions with relevant governmental agencies, e.g. forestry, mining, and agriculture; (iii) projection of landscape $\mathrm{C}$ emission estimates based on the existing Tanjabar development plan; (iv) constructing low $\mathrm{C}$ emission development pathways based on the projected $\mathrm{C}$ emission estimate; (v) calculating landscape $\mathrm{C}$ emission estimates based on the low $\mathrm{C}$ emission development pathways (decided in the previous step). The steps followed a framework described in Dewi et al. (2011), aiming to build a platform for negotiation between different stakeholders in planning development pathways that can reduce $\mathrm{C}$ emissions and, in general, enhance ecosystem services (ES) provisions.

The results of these evaluations formed the background of a recently published policy brief (Ekadinata et al. 2011). In the current paper, we combine these results with additional estimations of the uncertainty of $\mathrm{C}$ estimates at different spatial resolutions (described in the next session) in order to identify an appropriate scale for monitoring $\mathrm{C}$ emissions as performance measure for a REDD+ scheme.

2.3 Estimating the uncertainty of aboveground $\mathrm{C}$ emission estimates at different spatial resolutions

This study aimed to identify an appropriate spatial resolution for monitoring $\mathrm{C}$ emission estimates for the Tanjabar district that meet an error/accuracy threshold based on local conditions and acceptability of error. In this study we assume that uncertainty as a statistical property of $\mathrm{C}$ emission estimate might lead to error in implementation of REDD+ scheme. The study had two main steps:

(i) Developing $\mathrm{C}$ emission maps for Tanjabar from measured and observed changes in aboveground $\mathrm{C}$ stocks between 2000 and 2009. The $\mathrm{C}$ emission maps include uncertainty originating from errors in land cover map classifications and variations of $\mathrm{C}$ assessments (variations associated with land use/cover), and

(ii) based on the $\mathrm{C}$ emission maps developed in step (i), $\mathrm{C}$ emission estimates at various resolutions were calculated.

Lusiana et al. (in prep.) provide a detailed description of the methods used to generate the 2000-2009 C emission maps for Tanjabar and the associated effects of scale on estimated C emissions. A summary of the methods is also provided in Supplement 1 . The basis of the 
methods is that the uncertainty of $\mathrm{C}$ stocks of a $\mathrm{C}$ emission map can be quantified and generated using a Monte Carlo simulation approach, which is a statistical technique used to evaluate how errors propagate (Refsgaard et al. 2007). The $\mathrm{C}$ emission maps have $100 \mathrm{~m}$ resolution, similar to the resolution of the 2000 and 2009 land cover maps used in the analysis.

Based on the propagated $\mathrm{C}$ emission maps, we then carried out the spatial aggregation analysis that recalculated patch level $\mathrm{C}$ emission estimates using a moving window approach. The finest spatial resolution used was $100 \mathrm{~m}$, which was subsequently increased to emulate land holdings of individual households, local communities and villages within the district. Hence, the spatial resolution was varied from $100 \mathrm{~m}$ to $30,000 \mathrm{~m}$. Next, we evaluated the effect of resolution of the corresponding $\mathrm{C}$ emission map on the following attributes:

(i) Cumulative probability distribution of $\mathrm{C}$-emission estimates, that can provide information on percent of area sequestering or emitting $\mathrm{C}$;

(ii) uncertainty of pixel level $\mathrm{C}$ emissions indicating potential errors of $\mathrm{C}$ emission estimates relevant for determining an appropriate resolution for monitoring the performance of a REDD+ scheme; and

(iii) ability to identify $\mathrm{C}$ emission hotspots that are useful for stakeholders' negotiations preceding REDD+ project development and implementation.

The methods for these evaluations were (a) development of cumulative probability functions of $\mathrm{C}$ emissions, (b) estimation of standard deviation of $\mathrm{C}$ emissions and coefficient variation, and (c) $\mathrm{C}$ emission maps at various spatial resolutions.

A cumulative density function (cdf) was used to describe the cumulative probability of $\mathrm{C}$ emission estimates. It is basically a cumulative frequency distribution rescaled by the total frequency and thus its value spans between 0 and 1 . In this study, the cdf specifically describes the fraction of area that has $\mathrm{C}$ emission values at lower or equal to the associated value on the $\mathrm{X}$-axis.

Standard deviation of $\mathrm{C}$ estimates at resolution $p\left(s t d_{p}\right)$ is calculated based on the aggregated emission $\mathrm{C}$ maps developed for each spatial resolution, using the following equation:

$$
s t d_{p}=\left(\left(\sum_{k}\left(E_{k}-\left(\sum_{k} E_{k}\right) / n_{k}\right)^{2} / n_{k}\right)^{1 / 2}\right)
$$

where $E_{k}=$ estimated $\mathrm{C}$ emissions for pixel $k\left(\mathrm{Mg} . h a^{-1}\right)$, where $k=1, \ldots ., n, n=$ total number of pixels

The coefficient variation of $\mathrm{C}$ estimates at resolution $p\left(C V_{p}\right)$ is calculated using the following equation:

$$
C V_{p}=\left(s t d p_{p} /\left(\sum_{k} E_{k} / n_{k}\right)\right)
$$

2.4 Exploring stakeholders' views on fair distribution of benefits to be gained from REDD+ schemes

To explore stakeholders' perceptions and expectations for fair and efficient REDD+ schemes we used a framework named FERVA (fair and efficient REDD value-chain allocation) described by van Noordwijk (2008). The FERVA approach claimed that any future gain (payment) from REDD+ schemes is derived from a 'value-chain' of four main implementation efforts: (i) direct reduction of emissions, (ii) reorientation of development pathways and livelihood alternatives towards the maintenance of high $\mathrm{C}$ stock landscapes (as opposed to lucrative economic gains from deforestation), (iii) transaction costs incurred for participating in emission reduction schemes, 
including for monitoring, reporting and verification (MRV) processes, and (iv) activities to connect potential buyers with sellers, including raising awareness of the REDD+ project to potential buyers (cost to secure buyers). Activities (i) and (ii) occur at the local level, while most of activities (iii) and (iv) occur at the national and international level.

Following FERVA procedures, we held a focus group discussion (FGD) attended by 30 participants from Jambi province and Tanjabar: 10 people from local Non-Governmental Organization (NGOs) working on environmental issues and community empowerment, 10 local university staff and 10 government officials working on development planning, forestry, agriculture, environment and socio-economic issues. Stakeholders were asked to qualitatively allocate financial units over the four value-chain elements of REDD+ benefits (payment): (i) emission reductions, (ii) livelihood alternatives, (iii) transaction costs, and (iv) costs to secure buyers. The main outputs of this activity was a stakeholders' perspective on the expected current situation and desirable future distribution of benefits gained from the proposed REDD+ scheme(s), which is important and of relevance in the implementation of REDD+ in the local context.

\section{Results}

\subsection{Low emission development plan in Tanjabar: local planners' views}

The existing Tanjabar development plan categorized the district into twelve land use allocation zones (Table 1). The categorization was based on the $R T R W$ in combination with other land zoning maps developed by various governmental agencies such as the Indonesia Department of Forestry, Mining and National Land Bureau. In the existing development plan for Tanjabar District for 2010-2030, more than half of the area (54\%) is allocated to large-scale oil palm and industrial forest plantation companies (Fig. 2a, Table 1). It was projected that implementing the existing development plan would emit 36 carbon dioxide $\left(\mathrm{CO}_{2}\right) \mathrm{Mg} \mathrm{ha}^{-1}$ year ${ }^{-1}$ during the period 2009-2025 with the main sources of emissions from conversion of forest to oil palm and industrial forest plantation, including deforestation in peat forests (Ekadinata et al. 2011). Therefore to reduce $\mathrm{C}$ emissions, the local planning agency focused on modifying the existing development plan in zones allocated for industrial forest plantations, oil palm plantations, production forest and protected peat forest (Fig. 2b, Table 1) encompassing $63.7 \%$ of the total landscape as a potential area. The proposed low emission plan did not modify activities in the other allocation zones, thus activities in these areas would follow the existing plan. Hence, mining and conversion of forest to rubber systems would still be allowed to take place. Similarly, logging would continue within the areas already given to concessionaires.

Projection results showed that the proposed activities in low emission development could potentially reduce emissions by $27 \%$ by 2025 (Ekadinata et al. 2011). The highest potential reduction could be obtained from implementing low emission plans in areas allocated for oil palm plantations by prohibiting conversion of natural forests to oil palm and allocating new oil palm plantations to be established on degraded or abandoned land with lower $\mathrm{C}$ stocks.

\subsection{Scale effect on the distribution of $\mathrm{C}$ emission estimates}

The next three sections discuss the results from the uncertainty and scale study using the actual Tanjabar land cover maps of 2000 and 2009, but not the land zoning map (as described in the previous section).

The evaluated distribution of C emission estimates over the period 2000 - 2009 (9 years) at different spatial resolutions presented in Fig. 3 represents the percentage area that has $\mathrm{C}$ 
Table 1 Land use allocations in Tanjabar Indonesia showing current/existing development and proposed low $\mathrm{C}$ emission development plans

\begin{tabular}{|c|c|c|c|}
\hline $\begin{array}{l}\text { Development } \\
\text { zones }^{1}\end{array}$ & $\begin{array}{l}\text { Area } \\
\left(\mathrm{km}^{2}\right)\end{array}$ & Existing development plan & Low emission development plan $^{2}$ \\
\hline $\begin{array}{l}\text { Mining } \\
\text { concession }\end{array}$ & 12.5 & $\begin{array}{l}\text { To operate all current mining concession areas } \\
\text { existing land use will be converted to open } \\
\text { areas. Mining operations will adhere to } \\
\text { land reclamation and land restoration policies }\end{array}$ & n.a \\
\hline Production forest ${ }^{3}$ & 75.6 & $\begin{array}{l}\text { Non-concession areas will be developed } \\
\text { as buffer zones in the form of community } \\
\text { forests or ecotourism forests. }\end{array}$ & $\begin{array}{l}\text { Maintain undisturbed forest area } \\
\text { Establish rubber systems in } \\
\text { non-forested areas }\end{array}$ \\
\hline $\begin{array}{l}\text { Limited production } \\
\text { forest }^{4}\end{array}$ & 340.1 & $\begin{array}{l}\text { Non-concession areas will be developed as } \\
\text { buffer zones in the form of community } \\
\text { forests or ecotourism forest. }\end{array}$ & \\
\hline $\begin{array}{l}\text { Industrial forest } \\
\text { plantations }\end{array}$ & 1563.0 & $\begin{array}{l}\text { All land will be converted to Acacia mangium } \\
\text { plantations except for settlements, oil palm } \\
\text { systems and tree-based systems that already } \\
\text { exist in the area }\end{array}$ & $\begin{array}{l}\text { Avoid conversion of primary forest } \\
\text { to acacia, maintain existing } \\
\text { smallholders' tree-based systems } \\
\text { and expedite planting acacia in } \\
\text { shrub and grassland } \\
\text { areas within the concession } \\
\text { zone (5\% of total landscape area) }\end{array}$ \\
\hline Protected area & 109.7 & $\begin{array}{l}\text { The protected area will be maintained } \\
\text { as it is }\end{array}$ & n.a \\
\hline $\begin{array}{l}\text { Peatland protected } \\
\text { forest }\end{array}$ & 120.2 & $\begin{array}{l}\text { Forested area will be protected and oil palm } \\
\text { systems will be converted to mixed } \\
\text { tree-based systems by planting jelutung } \\
\left(\text { Dyera costulata }{ }^{6}\right)\end{array}$ & $\begin{array}{l}\text { Increase effort to maintain existing } \\
\text { forest area and establish Dyera } \\
\text { costulata systems. }\end{array}$ \\
\hline $\begin{array}{l}\text { Big scale oil palm } \\
\text { concession }\end{array}$ & 906.6 & Establishing large-scale oil palm plantations & $\begin{array}{l}\text { Prohibit conversion of forest to oil } \\
\text { palm ( } 2 \% \text { of total landscape area) }\end{array}$ \\
\hline Settlement & 21.0 & Expand and develop as needed & n.a \\
\hline $\begin{array}{l}\text { Irrigated agricultural } \\
\text { land }\end{array}$ & 231.3 & $\begin{array}{l}\text { Establishing paddy rice systems will be a } \\
\text { priority }\end{array}$ & n.a \\
\hline Dryland agriculture & 734.0 & $\begin{array}{l}\text { Establishing tree-based systems such as oil } \\
\text { palm, rubber, fruit and coconut }\end{array}$ & n.a \\
\hline Other land uses & 448.7 & $\begin{array}{l}\text { Establishing tree-based systems such as oil } \\
\text { palm, rubber, fruit and coconut }\end{array}$ & n.a \\
\hline Forest park ${ }^{7}$ & 18.8 & All land will be converted to rubber systems & n.a \\
\hline
\end{tabular}

(Source: Ekadinata et al. 2011)

${ }^{1}$ Based on Tanjabar district spatial land use plan (rencana tata ruang wilayah - RTRW) $2010-2030$ combined with other land zoning maps

${ }^{2}$ Proposed by Tanjabar district planning agency during participatory land use planning (LUWES) exercise

${ }^{3}$ Production forest is state forestland designated for production purposes

${ }^{4}$ Limited production forest is state forestland designated for limited production purposes

${ }^{5}$ Acacia mangium is a major tree species in plantations owned by large pulp and paper industries. Other uses include fuelwood, timber for building and furniture and particle boards

${ }^{6}$ Dyera costulata (local name: jelutung) is an endangered tree species mostly found in the rainforest of Indonesia, Malaysia and Thailand. Its latex is tapped for chewing gum and is mainly exported

${ }^{7}$ Locally known as taman hutan rakyat (Tahura) is an area designated for conservation in particular to preserve endemic and non-endemic flora and fauna for the purpose of research, science, education, cultivation, cultural, tourism and recreational purposes

n.a. not applicable, the low emission development plan proposed by local planners did not include these areas

emission values at lower or equal to the value on the $\mathrm{X}$-axis. At the original spatial resolution of $100 \mathrm{~m}$, the lowest $\mathrm{C}$ emission estimate was $-550 \mathrm{Mg} \mathrm{CO}_{2}$ eq. ha ${ }^{-1}$ (or equal to $61.1 \mathrm{Mg} \mathrm{CO}_{2}$ 


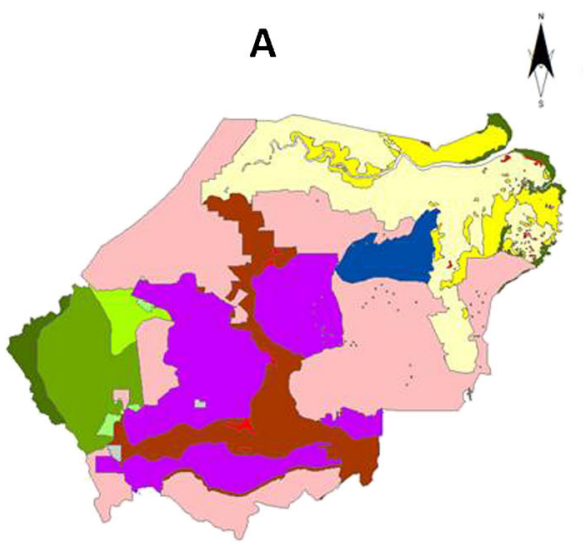

Development zones :

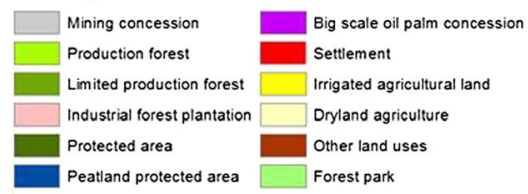

B

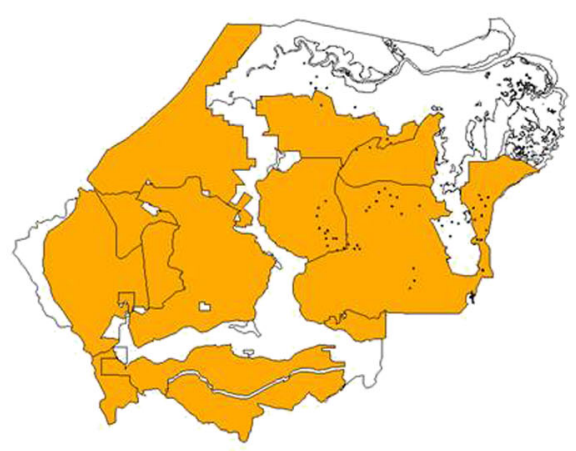

Proposed area for low emission development

Fig. 2 Map of Tanjabar district, a) current land use allocation zones of Tanjabar district as the basis for the new (low $\mathrm{C}$ emission) development plan and b) potential low $\mathrm{C}$ emission development activity areas (highlighted in orange) as planned by local stakeholders (modified from: Ekadinata et al. 2011). Table 1 provides description of each allocation zones

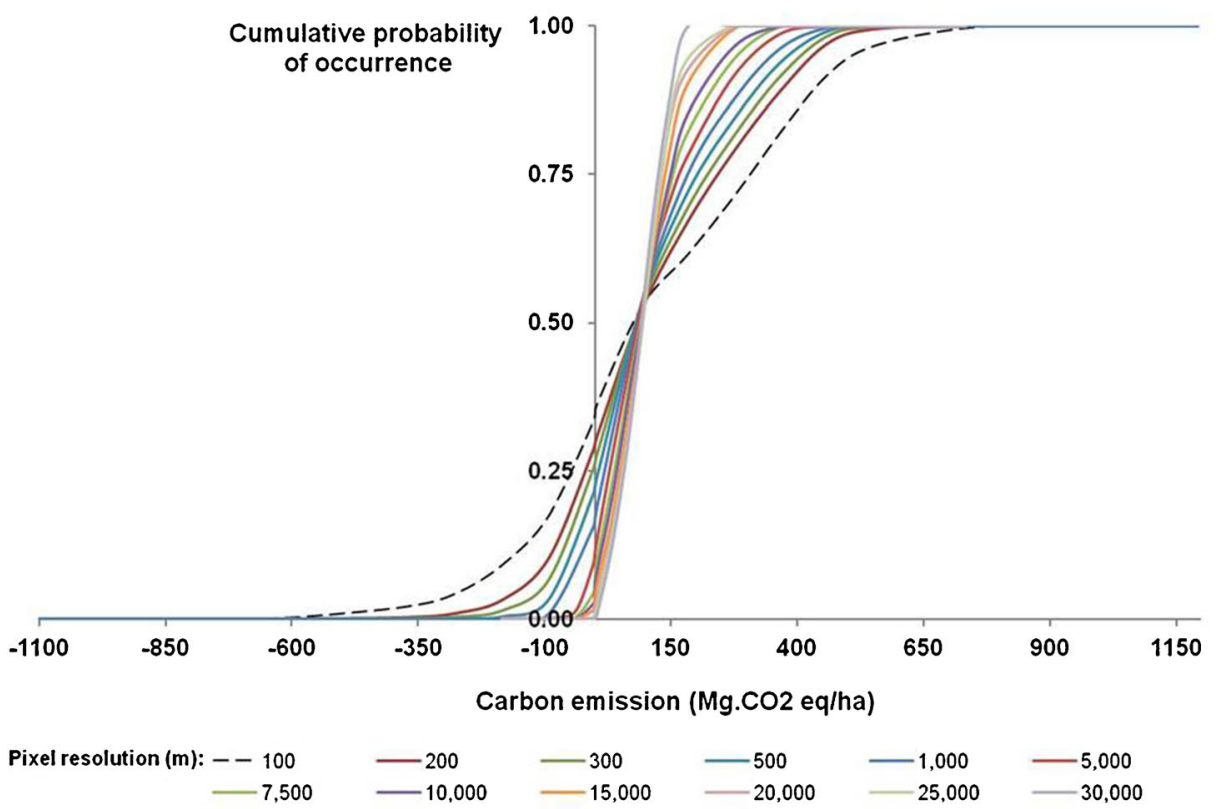

Fig. 3 Cumulative distribution functions of $\mathrm{C}$ emission estimates for Tanjabar, Jambi, Indonesia during the period 2000-2009 at different spatial resolutions. Pixel resolution of $100 \mathrm{~m}$ equals to pixel area of 1 ha and pixel resolution of $1,000 \mathrm{~m}$ equals to pixel area of $1 \mathrm{~km}^{2}$ 
eq. ha $^{-1}$ year $^{-1}$ sequestration), while at $200 \mathrm{~m}$ spatial resolution the lowest $\mathrm{C}$ emission was $-275 \mathrm{Mg} \mathrm{CO}_{2}$ eq. ha ${ }^{-1}$ (or equal to $30.6 \mathrm{Mg} \mathrm{CO}_{2}$ eq. ha ${ }^{-1}$ year ${ }^{-1}$ sequestration). Thus, the possible lowest $\mathrm{C}$ emission increased as spatial resolution decreased. An opposite trend occurred for the highest $\mathrm{C}$ emission, whereby the value decreased as spatial resolution decreased. Overall, as the spatial resolution decreased the $\mathrm{C}$ emission value shifted towards the average landscape $\mathrm{C}$ emission (at approximately $130 \mathrm{Mg} \mathrm{CO}_{2}$ eq. ha ${ }^{-1}$ ), which was also the value where all the cdf's converged.

Using the developed cdf, we can derive the proportion of area that has zero or lower $\mathrm{C}$ emissions between year 2000 and 2009 for different spatial resolutions (Fig. 4). Thus, this function denotes the proportion of $\mathrm{C}$ sequestration area $\left(P_{C s e q}\right)$ in the landscape and can then provide an indication of the potential area eligible for receiving emission reduction incentives via the REDD+ scheme under certain program designs. For the Tanjabar landscape, at $100 \mathrm{~m}$ spatial resolution the $P_{C s e q}$ value was $34.8 \%$. The $P_{C s e q}$ value decreased along with the decrease of spatial resolution reaching $0 \%$ at a pixel length of $30,000 \mathrm{~m}$ (or equal to a pixel size of $900 \mathrm{~km}^{2}$ ). Consequently, decreasing the spatial resolution has led to loss of information on potential pixels/areas that sequestered $\mathrm{C}$; hence also a loss of information about potential areas eligible (under certain program designs) for receiving incentives from the REDD+ scheme(s) occurred.

\subsection{Scale effects on uncertainty of $\mathrm{C}$ estimates}

The uncertainty of $\mathrm{C}$ estimates (represented by the coefficient of variation) decreased with the decrease of spatial resolution (Table 2). As spatial resolution decreased, neighboring pixels were aggregated and averaged forming a new value. Thus, variation that may have existed between neighboring pixels was reduced or lost, while the overall average value was more or less intact. Consequently, the coefficient variation values followed the trajectory of spatial resolution.

Depending on a given threshold value for acceptable error in implementing an incentive scheme, we can propose an appropriate scale for monitoring $\mathrm{C}$ emissions to be used in the

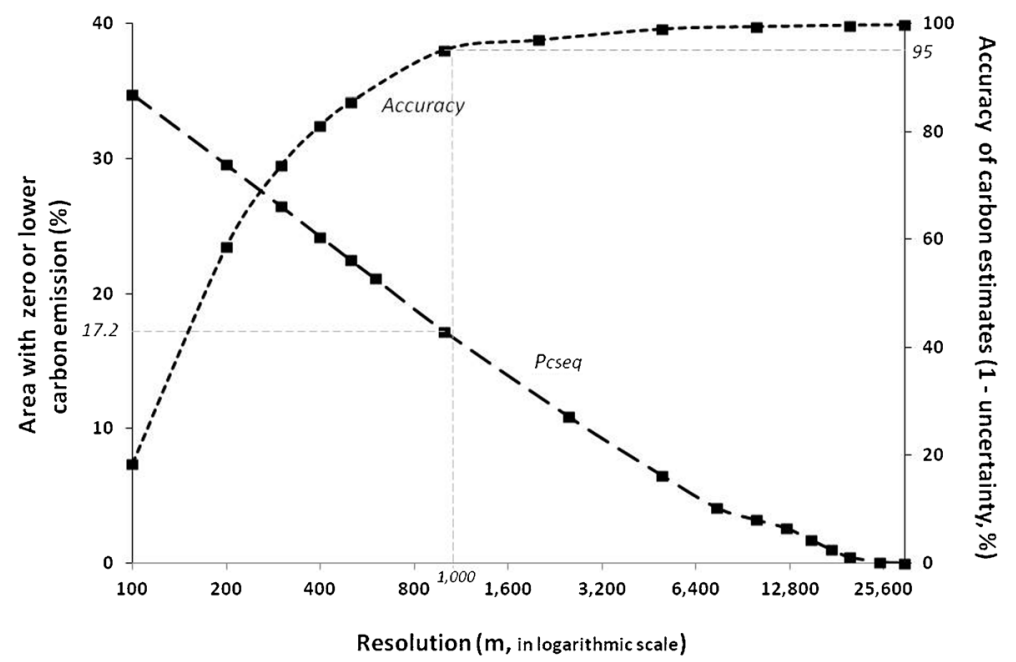

Fig. 4 Potential $\mathrm{C}$ sequestration area $\left(P_{C s e q}\right)$ and accuracy (1- uncertainty) of $\mathrm{C}$ estimates at different spatial resolutions for Tanjung Jabung Barat (Tanjabar) Jambi during the period 2000-2009. Pixel resolution of $100 \mathrm{~m}$ equals to pixel area of 1 ha and pixel resolution of $1,000 \mathrm{~m}$ equals to pixel area of $1 \mathrm{~km}^{2}$ 
Table 2 Uncertainty of C emisions for Tanjung Jabung Barat (Tanjabar), Jambi, Indonesia from 2000 and 2009
${ }^{\mathrm{a}}$ Based on 100,000 Monte Carlo generated $\mathrm{C}$ emission maps

\begin{tabular}{|c|c|c|}
\hline $\begin{array}{l}\text { Spatial } \\
\text { resolution }(\mathrm{m})\end{array}$ & $\begin{array}{l}\text { Standard deviation }{ }^{\mathrm{a}} \\
\left(\mathrm{Mg} \cdot \mathrm{CO}_{2} \text { eq.ha }{ }^{-1}\right)\end{array}$ & $\begin{array}{l}\text { Coefficient of variation } \\
\text { (uncertainty) }(\%)^{\mathrm{a}}\end{array}$ \\
\hline 100 & 93.5 & 81.54 \\
\hline 200 & 47.3 & 41.37 \\
\hline 300 & 30.1 & 26.31 \\
\hline 400 & 21.6 & 18.91 \\
\hline 500 & 16.8 & 14.59 \\
\hline 1,000 & 5.7 & 4.91 \\
\hline 2,000 & 3.6 & 3.11 \\
\hline 5,000 & 1.2 & 1.05 \\
\hline 10,000 & 0.7 & 0.60 \\
\hline 20,000 & 0.4 & 0.34 \\
\hline 30,000 & 0.3 & 0.22 \\
\hline
\end{tabular}

proposed REDD+ scheme (Fig. 4). For example, using a threshold of $5 \%$ error (or $95 \%$ accuracy) the corresponding unit for performance measure is $\mathrm{C}$ emission map with pixel resolution of $1,000 \mathrm{~m}$ or equal to a pixel size of $1 \mathrm{~km}^{2}$. A lower error threshold implies the need for a higher spatial resolution (larger pixel size) as a performance measure in the REDD+ MRV scheme, and vice versa a higher uncertainty threshold implies a lower spatial resolution (smaller pixel size) can be used for performance measures.

\subsection{Spatial pattern of $\mathrm{C}$ emission hot spots}

Spatial information on hot spots of $\mathrm{C}$ emissions and sequestration is useful in targeting areas for REDD+ implementation. Figure 5 provides information on the location of net $\mathrm{C}$ emissions areas (red) and $\mathrm{C}$ sequestration areas (green). Figure 5 is basically a spatial image representation of the $c d f$ graph shown in Fig. 3. It shows how $\mathrm{C}$ emissions are distributed spatially across the landscape. Carbon emission maps with 1,000 $\mathrm{m}$ and 2,500 $\mathrm{m}$ resolution are compatible with the location for the proposed low emission activities depicted in Fig. 2. It shows the area where $\mathrm{C}$ sequestration will be maintained (forest peat land in green, Fig. 5) and $\mathrm{C}$ emissions will be reduced (zone allocated for large scale plantations in red, Fig. 5).

Areas of the greatest source of $\mathrm{C}$ emissions were identified as oil palm and industrial forest plantations converted from disturbed forest, while areas of greatest $\mathrm{C}$ sink were rubber and coconut/bettlenut agroforesty systems converted from agriculture and shrub areas (Ekadinata et al. 2011, Lusiana et al. in prep.).

The $\mathrm{C}$ emission maps with decreasing spatial resolutions provide different perspectives on the location of hotspot areas. An extreme comparison showed that $\mathrm{C}$ sequestration areas identified at $100 \mathrm{~m}$ resolution had completely disappeared at $30,000 \mathrm{~m}$ resolution.

\subsection{Fair distribution of emission reduction incentives scheme: stakeholders' perspectives}

In evaluating the allocation of economic benefits of a certain emission reduction scheme, the stakeholders were grouped into $\mathrm{NGO}(\mathrm{n}=10)$, government $(\mathrm{n}=10)$ and researchers $(\mathrm{n}=10)$. Each group were asked to assess the expected distribution of the allocation of REDD+ benefits and what the desirable distribution should be, with respect to the four elements involved in implementation of REDD+ schemes: (i) direct emission reduction, (ii) finding sustainable 


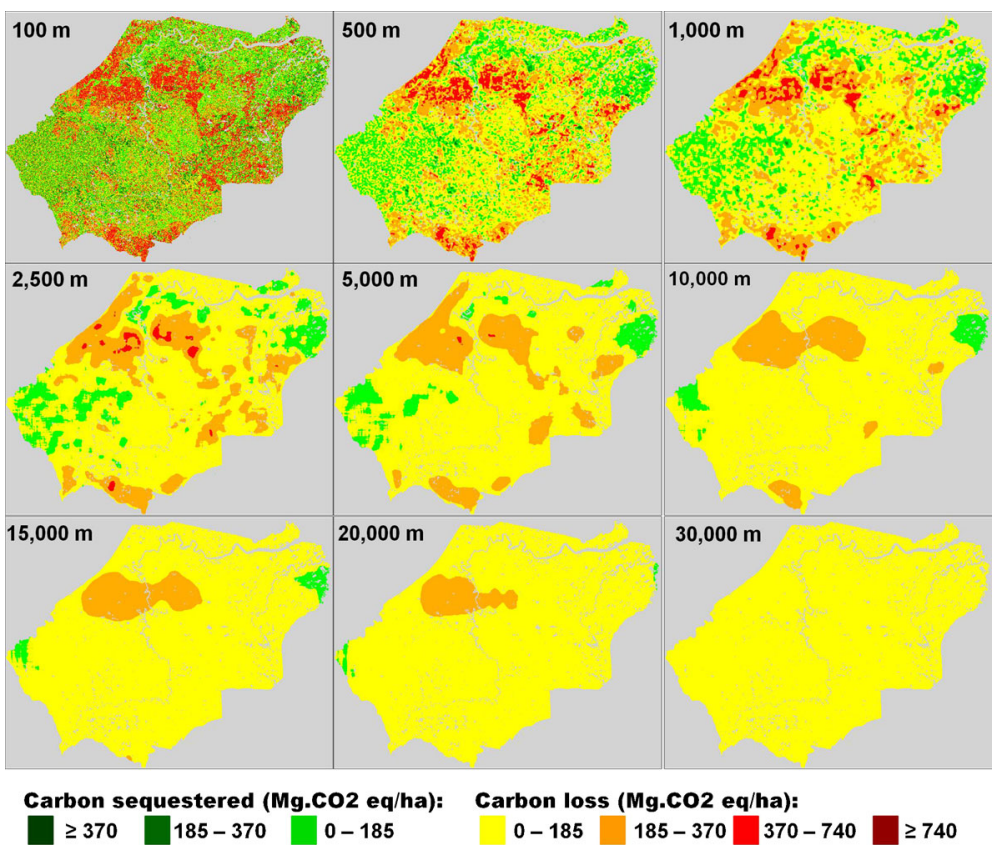

Fig. 5 The effect of scale on hot spots of C emissions in Tanjabar, Jambi, Indonesia between 2000 and 2009. Pixel resolution of $100 \mathrm{~m}$ equals to pixel area of 1 ha and pixel resolution of $1,000 \mathrm{~m}$ equals to pixel area of $1 \mathrm{~km}^{2}$

livelihood alternatives, (iii) transaction costs (including cost of MRV), and (iv) cost to secure buyers. The result of the FGD indicated that all stakeholders expected that benefits would mostly be allocated for 'transaction costs and MRV procedures', i.e. $48 \%, 35 \%$ and $50 \%$ by NGO, government and researchers respectively (Fig. 6). However, most stakeholders desired the transaction costs to receive lower financial allocation, except for the government who wished an increase in allocation by $10 \%$ from what they expected it would be. Compared to the other stakeholders, NGOs expected the allocation for direct emission reduction and finding sustainable livelihood alternatives components would be higher compared to transaction costs and cost to secure buyers. They also desired that $87 \%$ of the benefits derived from the REDD+ scheme should be allocated to this component. This was strikingly different to the desire of the government and researchers with $35 \%$ and $20 \%$, respectively. Nevertheless, all stakeholders agreed that ideally allocation for emission reduction and sustainable livelihood components should be higher than currently expected, while allocation 'to secure buyers' should be lower. Government expected that a large part of the benefits be allocated to secure buyers (40\%) compared to the $10 \%$ and $30 \%$ by NGOs and researchers.

\section{Discussion}

4.1 What level of spatial aggregation is appropriate for an incentive scheme for emission reduction in Tanjabar?

Carbon emission reduction estimates at any scale combine signal (actual $\mathrm{C}$ emission) and noise (uncertainty in measurement of land use change and associated C stocks). An incentive 


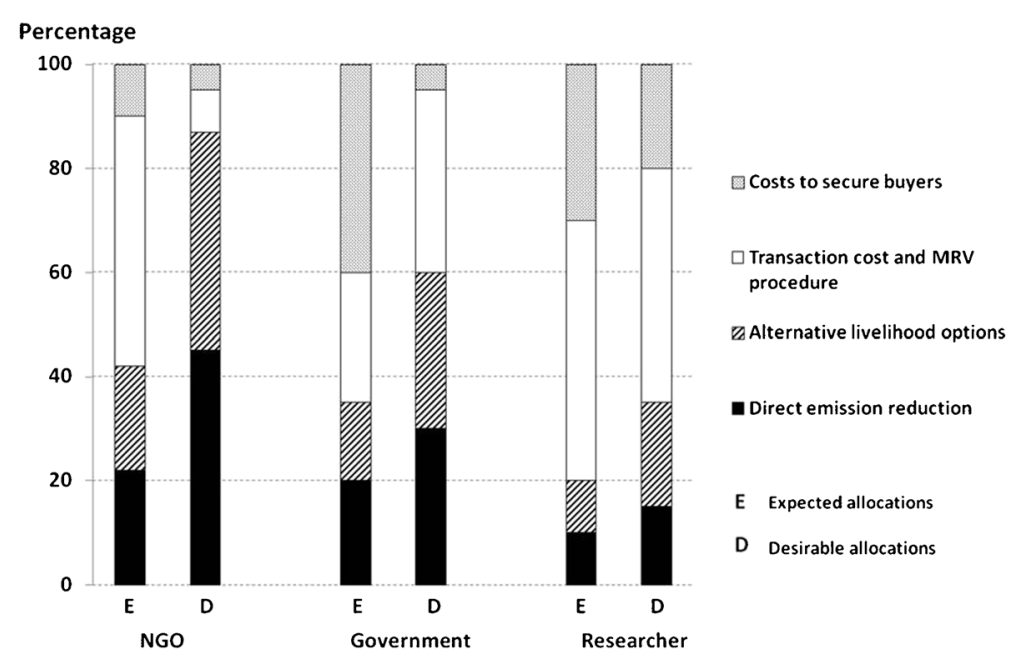

Fig. 6 Proposed allocation of benefits (proportion of total $\mathrm{C}$ payment) to the REDD+ value chain in both expected and desired scenarios according to the stakeholders of Tanjabar, Jambi, Indonesia

scheme for emission reduction requires performance measures for monitoring changes at the landscape scale with a clear signal and low noise. Uncertainty or noise setting the threshold for an acceptable error at $5 \%$, a decrease in spatial resolution from $100 \mathrm{~m}$ ( 1 ha pixel size) of an interpreted land cover change map to a $1,000 \mathrm{~m}\left(1 \mathrm{~km}^{2}\right.$ pixel size $)$ would be required in the Tanjabar landscape for monitoring emission changes. If a $1 \mathrm{~km}^{2}$ grid size were applied, the major differentiations of high and low emission areas within the district could still be maintained (Fig. 5). However, at the $1 \mathrm{~km}^{2}$ performance scale, only $17.2 \%$ of the Tanjabar area had a zero or negative $\mathrm{C}$ emission estimate over the observation period and would therefore be eligible to receive incentives under a hypothetical emission reduction incentive scheme, while at a 1 ha scale twice this fraction of pixels would appear to be eligible if a higher uncertainty was tolerated (Fig. 4). The average landholding of farmers in Tanjabar ranged from 4 to 8 ha, depending on where they were operating (peat or mineral soils) and who they were (migrant or local farmers) (Khususiyah and Suyanto 2012). Thus, at a $1 \mathrm{~km}^{2}$ performance scale the emission reduction scheme will not be targeting individual farmers, but more likely villages or farmer groups.

The $5 \%$ threshold is rather arbitrary in the absence of specific research on tolerance to uncertainty of REDD+ or PES implementation schemes in general. Further empirical data on such tolerance levels will be needed in order to better justify necessary designs. The threshold uncertainty would function as an indicator of how much uncertainty can be tolerated in the case where $\mathrm{C}$ emission reduction payments would be off target, i.e. eligible ES providers did not get any payment or ineligible ES providers got paid. A welfare aid program in the US used two separate tolerance levels, $5 \%$ for payment for ineligible recipients and $3 \%$ for overpayment or underpayment to eligible recipients (Griswold and Spurrier 1975).

The current assessment was based on aboveground C stock estimates, but evidence for Jambi suggests that land use effects on belowground C stocks on mineral soils are strongly related to aboveground changes (van Noordwijk et al. 2013). The spatial distribution of peat and peat depth in Tanjabar district, however, adds further uncertainty, as transitions between mineral and peat soils tend to be gradual. Future spatial aggregation and uncertainty studies 
that combine above and below ground $\mathrm{C}$ stock change in the district would increase its local relevance, but would make it less applicable elsewhere.

4.2 How can efficiency, fairness and transaction costs be balanced in the design of emission reduction or REDD+ mechanism?

As suggested from the experience PES implementation (Wunder et al. 2008), spatial aggregation (and hence larger area) is likely to reduce transaction costs, particularly for carrying out MRV procedures. All stakeholders, both in expected and desired configurations, agreed on an approximately 50-50 \% split between emission reduction developing alternatives for livelihood options. However, they differed in expectations about the share that costs-to-secure-buyers plus transaction costs would take. They agreed that costs-to-securebuyers and transaction costs should be reduced $(65,40$ or $15 \%$ of the total benefit for academicians, government officials and NGO participants, respectively), but differed in the proportion they would be willing to allocate to transaction costs (including MRV): this ranged from $40 \%$ for academicians to $8 \%$ for NGO-participants. A more detailed costing of the components of MRV in relation to scale will be needed. However, the use of a $1 \mathrm{~km}^{2}$ performance measure, of lower resolution than most land cover maps, is likely to shift transaction costs to a lower value, which is a desirable direction from the stakeholders' perspectives (Börner and Wunder 2008).

In addition to the spatial scale of efficiency discussed above, a temporal perspective on efficiency is also relevant. Efforts towards direct emission reduction are aiming to gain shortterm efficiency, while efforts for 'finding livelihood alternatives' encompass finding options to avoid potential emission reduction. This in turn is aiming for long-term efficiency as well as finding options to support sustainable livelihoods as part of gaining fairness. Thus, at intermediate or long-term temporal scale, efficiency and fairness converged.

4.3 How do local planners prioritize $\mathrm{C}$ emission reduction with economic growth in the district?

Potential REDD+ activities developed by local planners are compatible with the $1 \mathrm{~km}^{2}$ aggregated $\mathrm{C}$ emission 'hot-spot' map (Figs. 3 and 5). Local planners recommended that emission reduction schemes in Tanjabar should focus on three allocation zones that were the main source of C emissions: industrial tree plantations (HTI), oil palm plantations (HGU) and peatland forest management units (KPHLG). However, these areas were also the main land use systems contributing to economic growth in the area (Sofiyuddin et al. 2012). Thus, in the modified Tanjabar development plan, local planners proposed activities that maintain the use of these areas for productive purposes; while at the same time increasing $\mathrm{C}$ sequestration by encouraging optimized use of abandoned and degraded land through the establishment of agroforestry systems that potentially can be managed by local farmers. Therefore, the establishment of agroforestry systems could also provide alternative livelihood options for farmers. Local planners also proposed allocation of conservation zones within the allocated oil palm plantation zone, albeit at a small fraction of $2 \%$.

Other emission reduction activities include encouraging the use of raw materials (for timber or plywood) from planted trees and reduce (or even forego) the use of wood from natural forests (Ekadinata et al. 2011). The potential emission reduction activities developed and proposed by local planners avoid drastic change that solely aimed for emission reduction as they understood the importance of maintaining economic growth as well. This approach appropriately matched the desires of the other stakeholders participating in the FGD when 
asked to allocate benefits from a hypothetical emission reduction scheme, which is to maximize the allocation for livelihood benefits.

4.4 Optimizing efficiency and stakeholders' perspectives for developing the REDD+ scheme in Tanjabar

Many stakeholders are involved in natural resource management, hence sustainable natural resource management requires a reconciliation of multiple knowledge systems: local, government, and science-based (Clark et al. 2011). In such a context, quality criteria for the application of science in natural resource management involve salience (actionable conclusions), credibility (evidence-based and empirically tested theoretical frameworks, explicitness of assumptions, and analysis of confidence intervals) and legitimacy (matching multiple stakeholder perceptions of representing their perspectives) (Lusiana et al. 2011). The current study met these requirements; whereby the actionable conclusion is a set of REDD + plan activities derived from land use planning and $\mathrm{C}$ emission maps (at various scales with estimated uncertainty). This became a basis for performance based rewards and stakeholders' evaluation on what they perceived as fair and efficient benefit allocation of a future REDD+ scheme.

Tanjabar C emission maps were derived from 1 ha scale land cover maps, while a stakeholder REDD+ activities plan was based on land allocation maps with its zone allocation as the scale of its unit activities. These different units of scale were able to be reconciled at a $1 \mathrm{~km}$ scale. Matching the institutional scale and the scale at which ES performance were based is important to support the formulation or implementation of ES management (Hein et al. 2006).

A quantitative approach to the issue of scale in REDD+ or PES designs based on the tolerance for uncertainty in the implementation stage has, to our knowledge, not been previously attempted. It can add perspectives to the spatial analysis of co-benefits that makes use of the spatial correlation of determinants of biodiversity and $\mathrm{C}$ stock values (Strassburg et al. 2010), or biodiversity and watershed functions (Douglas et al. 2007). The $1 \mathrm{~km}^{2}$ scale identified in this study, applies to its specific spatial properties of land cover and land use change, as well as the reliability of the land use change detection method and $\mathrm{C}$ stock uncertainty. However, replication of the approach in other landscapes may yield different results, depending on the quality of $\mathrm{C}$ and land cover data, as well as type of land use change activities (Pelletier et al. 2011). For the Tanjabar case, improved methods in the future could be aimed at increasing the spatial resolution feasible within the tolerated uncertainty range.

REDD+ designs should not only take care of the uncertainty of MRV, but need to also look into the social uncertainty related to land tenure security in the area (Galudra et al. 2013). Harmonization between district (Tanjabar) and provincial (Jambi) spatial planning as well as with large-scale operators (industrial plantations and oil palm) and local people/farmers are necessary for developing effective and equitable implementation of national REDD+ programs.

\section{Conclusion}

An uncertainty assessment of $\mathrm{C}$ emissions combined with spatial aggregation analysis can provide insights into how $\mathrm{C}$ emissions are distributed within the landscape. The outcome can provide recommendations on units for performance measures that can support efficient implementation of the REDD+ scheme. For Tanjabar, using $1 \mathrm{~km}^{2}$ spatial aggregation the uncertainty in $\mathrm{C}$ emission estimates dropped below $5 \%$, while much of the spatial pattern of the original pixel level $\mathrm{C}$ (high and low emissions) in the area is retained. Fairness and 
transaction cost issues in the design of REDD+ mechanisms are also recognized by local stakeholders, who converge on an equal allocation to short-term efficiency and long-term fairness aspects. Feasible measures for emission reduction in the district, as derived from a participatory planning process, are compatible with the $1-\mathrm{km}^{2}$ aggregation level of spatial performance data. Efforts should be made to improve methods that allow reducing uncertainty/variability in $\mathrm{C}$ estimates as these could increase the potential area/beneficiaries from $17.2 \%$ at $1 \mathrm{~km}^{2}$ patch size to $34.8 \%$ at 1 ha patch size. The uncertainty analysis combined with spatial approach has the potential to support REDD+ activities, in particular identifying the right scale for each of the steps of MRV activities.

Acknowledgement This study is funded by BMZ/GTZ-Germany through the project 'Trees in multi-Use Landscapes in SouthEast Asia' (TULSEA), by European Union (EU) through 'Reducing Emissions from Deforestation and Degradation through Alternative Land uses in Rainforests of the Tropics' (REDD-ALERT) project and by NORAD-Norway through 'Reducing Emission from All Land Uses' (REALU) project. We thank Sonya Dewi and Beria Leimona for their feedback during this study.

Open Access This article is distributed under the terms of the Creative Commons Attribution License which permits any use, distribution, and reproduction in any medium, provided the original author(s) and the source are credited.

\section{References}

Agrawal A, Nepstad D, Chhatre A (2011) Reducing emissions from deforestation and forest degradation. Annu Rev Env Resour 36(1):373-396

Angelsen A, Streck C, Peskett L, et al (2008) What is the right scale for REDD? In: Angelsen, (ed.) Moving Ahead with REDD: Issues, Options and Implications. CIFOR, Bogor, Indonesia

Börner J, Wunder S (2008) Paying for avoided deforestation in the Brazilian Amazon: from cost assessment to scheme design. IFR 10(3:496-511)

Canadell JG, Le Quéré C, Raupach MR, et al (2007) Contributions to accelerating atmospheric $\mathrm{CO}_{2}$ growth from economic activity, carbon intensity, and efficiency of natural sinks. PNAS 104(47):18866

Cattaneo A (2011) Robust design of multiscale programs to reduce deforestation. EDE 16(Special Issue $04): 455-478$

Clark WC, Tomich TP, van Noordwijk M et al (2011) Boundary work for sustainable development: Natural resource management at the Consultative Group on International Agricultural Research (CGIAR). PNAS Early Edition. doi:10.1073/pnas.0900231108

Dewi S, Ekadinata A, Galudra G, et al (2011) LUWES: Land Use planning for loW Emission development Strategy. World Agroforestry Centre, Bogor, Indonesia

Douglas E, Wood S, Sebastian K et al (2007) Policy implications of a pan-tropic assessment of the simultaneous hydrological and biodiversity impacts of deforestation. Water Resour Manag 21(1):211-232

Ekadinata A, Agung P, Galudra G, et al (2011) Planning for low-emissions development in Tanjung Jabung Barat district, Jambi province, Indonesia. Brief No 20. p. 6, World Agroforestry Centre, ICRAF-SEA Regional Office, Bogor, Indonesia

Galudra G, Agung P, van Noordwijk M, et al (2013) Migrants, land markets and carbon emissions: the drivers of land tenure change and the prospect of REDD+ in Jambi, Indonesia. Miti \& Adapt Strat for Glob Change. doi:10.1007/s11027-013-9512-9

Griswold JS, Spurrier PG (1975) Identification of error-prone cases in AFDC quality-control corrective action. Soc Serv Rev 49(3):421-429

Hein L, van Koppen K, de Groot RS et al (2006) Spatial scales, stakeholders and the valuation of ecosystem services. Ecol Econ 57(2):209-228

Hoang MH, Do TH, Pham MT et al (2013) Benefit distribution across scales to reduce emissions from deforestation and forest degradation (REDD+) in Vietnam. Land Use Policy 31:48-60

Khususiyah N SM, and Suyanto S (2012) Strategi Sumber Penghidupan Petani di Tanjung Jabung Barat (Livelihood strategies of farmers in Tanjung Jabung Barat). Brief No 22, p. 4, World Agroforestry Centre ICRAF, SEA Regional Office, Bogor, Indonesia. 
Le Quere C, Raupach MR, Canadell JG et al (2009) Trends in the sources and sinks of carbon dioxide. Nat Geosci 2(12):831-836

Lusiana B, van Noordwijk M, Suyamto D, et al (2011) Users' perspectives on validity of a simulation model for natural resource management. Int J Agric Sustai 9(2):364-378

Minang PA, van Noordwijk M (2013) Design challenges for achieving reduced emissions from deforestation and forest degradation through conservation: Leveraging multiple paradigms at the tropical forest margins. Land Use Policy 31:61-70

Mulia R, Widayati A, Suyanto S, et al (2013). Low carbon emission development strategies for Jambi, Indonesia: simulation and trade-off analysis using the FALLOW model. Miti \& Adapt Strat for Glob Change. doi:10.1007/s11027-013-9485-8

Murphy D (2011) Safeguards and multiple benefits in a REDD+ mechanism., p. 37, International Institute for Sustainable Development, Winnipeg, Canada

Pedroni L, Dutschke M, Streck C et al (2009) Creating incentives for avoiding further deforestation: the nested approach. Clim Policy 9(2):207-220

Pelletier J, Ramankutty N, Potvin C (2011) Diagnosing the uncertainty and detectability of emission reductions for REDD+ under current capabilities: an example for Panama. Environl Res Lett 6(2):024005

Peters GP, Marland G, Le Quere C, et al (2012) Rapid growth in $\mathrm{CO}_{2}$ emissions after the 2008-2009 global financial crisis. Nature Clim Change 2(1):2-4

Refsgaard JC, van der Sluijs JP, Højberg AL, et al (2007) Uncertainty in the environmental modelling process - A framework and guidance. Environ Modell Soft 22(11):1543-1556

Sofiyuddin M, Rahmanulloh A, Suyanto S (2012) Assessment of profitability of land use systems in Tanjung Jabung Barat District, Jambi Province Indonesia. Open J For 2(4):252-256

Strassburg BBN, Kelly A, Balmford A et al (2010) Global congruence of carbon storage and biodiversity in terrestrial ecosystems. Conserv Lett 3(2):98-105

van Noordwijk M (2008) Fair \& Efficient REDD Value Chains Allocation (FERVA). p. 4, World Agroforestry Centre - ICRAF, SEA Regional Office. Bogor, Indonesia

van Noordwijk M, Leimona B, Jindal R et al (2012) Payments for Environmental Services: evolution towards efficient and fair incentives for multifunctional landscapes. Annu Rev Env Resour 37(1):18.11-18.32

van Noordwijk M, Agus F, Rahayu S, et al (2013) Soil-based C emissions due to land use change in Jambi province (Sumatra, Indonesia). Miti \& Adapt Strat for Glob Change (in press)

Wösten JHM, Ismail AB, van Wijk ALM (1997) Peat subsidence and its practical implications: a case study in Malaysia. Geoderma 78(1-2):25-36

Wunder S, Engel S, Pagiola S (2008) Taking stock: a comparative analysis of payments for environmental services programs in developed and developing countries. Ecol Econ 65(4):834-852 